\title{
Yönetici Desteğinin İşe Adanmışlık Üzerindeki Etkisinde Psikolojik Sahiplenmenin Aracı Rolü
}

\author{
Ergün $\mathrm{KARA}^{1}$ ve Attila KAYA ${ }^{2}$
}

$\ddot{O} z$

Bu çalşşmanın amacı yönetici desteğinin işe adanmışlık üzerindeki etkisinde psikolojik sahiplenmenin aracılık rolünün araştırlmasıdır. Bu amaç doğrultusunda Balıkesir ve Çanakkale illerindeki seyahat acentelerinde çalışan toplam 245 katıllımcıdan anket aracılı̆̆gyla veri toplanmışır. Çalışmada öncelikle değişkenler arasındaki ilişkiyi ele alan araştırmalar incelenmiş ve bu doğrultuda hipotezler oluşturulmuştur. Elde edilen veriler ışı̆̆ında, SPSS ve AMOS programları kullanılarak araştırma hipotezleri sınanmıştır. Ölçek geçerliliği için doğrulayıcı faktör analizi (DFA) yapılarak, değişkenler arası ilişkiler tespit edilmiş ve yapısal eşitlik modeli (YEM) ile modelin uyum iyiliği testleri ve regresyon analizi yapılmıştır. Aracılık rolünü test edebilmek için ise dolaylı etkilerin anlamllığına bakılmış ve bunun için boostrap yöntemi kullanılmıştır. Yapılan analizlerde, yönetici desteğinin işe adanmışlık ve psikolojik sahiplenme değişkenlerini pozitif yönde anlamlı olarak etkilediği tespit edilmiștir. Aracllık analizi neticesinde ise psikolojik sahiplenmenin yönetici desteği ile işe adanmışlı arasındaki ilişkide kısmi aracılık rolü olduğu tespit edilmiştir. Çalışmanın alan yazınına teorik ve pratik olarak katkı sağlayacağı düşünülmektedir. Bu kapsamda çalışmanın gelecekte yapılacak olan çalışmalara ve uygulayıcılara 1şık tutması yönünde çeşitli önerilerde bulunulmuştur.

Anabtar Kelimeler: Yönetici Desteği, İșe Adanmışlık, Psikolojik Sahiplenme

\section{The Mediating Role of Psychological Adoption in the Influence of Executive's Support} on Dedication to Work

\section{Abstract}

The aim of this research is to investigate the mediating role of psychological adoption in the influence of executive's support on work dedication. For this purpose, data was collected from a total of 245 participants operating in travel agencies in Balıkesir and Çanakkale provinces. In the study, the researches dealing with the relationship between the variables were first examined and hypotheses were created accordingly. In the light of the data provided, research hypotheses were tested using SPSS and AMOS programs. Confirmatory factor analysis (CFA) was done for scale validity, relationships between variables were found out, and structural equation model (SEM), goodness-of-fit tests and regression analysis were done. In order to test the mediation role, the significance of indirect influences was examined and the boostrap method was used for this purpose. In the analyzes conducted, it was found out that the support of the manager affected the variables of work dedication and psychological adoption positively and significantly. As a result of the mediation analysis, it was determined that psychological ownership has a partial mediating role in the relationship between executive support and commitment to work. It is thought that the study will contribute theoretically and practically to the literature. In this context, various suggestions were made to shed light on future studies and practitioners.

Key Words: Executive's Support, Dedication to Work, Psychological Adoption

\section{Atıf İçin / Please Cite As:}

Kara, E. ve Kaya, A. (2020). Yönetici desteğinin işe adanmışlı üzerindeki etkisinde psikolojik sahiplenmenin aracı rolü. Manas Sosyal Arastrmalar Dergisi, 9(4), 2364-2375.

Geliş Tarihi / Received Date: 01.05.2020

Kabul Tarihi / Accepted Date: 13.07.2020

\footnotetext{
${ }^{1}$ Doç. Dr. - Osmaniye Korkut Ata Üniversitesi İktisadi ve İdari Bilimler Fakültesi, ergunkara@osmaniye.edu.tr ORCID: 0000-0002-7815-1111

2 Dr. Öğrencisi - Osmaniye Korkut Ata Üniversitesi, Sosyal Bilimler Enstitüsü, akaya501616@gmail.com ORCID: 0000-0002-2479-5173
} 


\section{Giriş}

Günümüzde örgütlerin kullanabileceği bilișim ve teknoloji her ne kadar üst seviyeye çikmıș olsa da artan ve güçlenen rakipler karşısında ihtiyaç duyulan kalifiye eleman ihtiyacının önemi de giderek artmaktadır. Modern örgütlerde iş gücünün tanımı artık fiziksel kuvvete dayanan güç olarak tanımlanmamaktadır. İleriyi görebilen, özgün yeni fikirler ortaya koyabilen ve örgütleri için değer üretebilen çalışanların varllğı önemlidir. Bu süreç içerisinde çalısanlarına her türlü desteği veren, onların gelişimi ile yakından ilgilenen örgütlerin daha başarılı olduğu söylenebilir. Örgütlerin bu başarısında benimsemiş oldukları iş gücü politikalar kadar, o politikaları uygulamaya koyan yöneticilerin uygulama süreçleri içerisindeki tutum ve davranışları başarı veya başarısızlığı doğrudan etkileyebilmektedir. Çalışanlarını destekleyen, hatalarında onlara yol gösterici olan, cezalandırıcı değil ödüllendirici bir yol izleyen, gelişimleri ile yakından ilgilenen ve gerektiğinde ona arkadaş gibi davranan yöneticilerin varllğı oldukça önemlidir.

İse adanmışlık kavramı son yıllarda üzerinde durulan güncel örgütsel davranış kavramları arasında yer almaktadır (Kırpık, 2020). Çalışanların örgütlerde işe adanmışlığında, örgüt tarafından kendilerine sağlanan hakların varlığının yanı sıra yönetenlerin desteği de etkili olmaktadır. Yöneticinin çalışma alanında yapacağı her türlü hareket çalışanlar tarafindan kendilerine karşı bir tutum olarak algılayarak olumlu ya da olumsuz olarak değerlendirilmektedir. Çalışanlarda kariyer planlamasında da önemli bir yere sahip olan ve elinde birçok imkanı bulunduran yöneticinin, bu imkanları olumlu yönde kullanması, iş görenler arasında eşit firsatlara yer vermesi ve başarılarının takdir edilmesi yönünde çalışan beklentileri bulunmaktadır (Kim vd., 2017). Diğer yandan çalışanların işe adanmışlığında önemli etkenlerden birisi de psikolojik sahiplenmedir. Psikolojik sahiplenme çalışanın örgütü kendisine aitmiş gibi hissetmesini ve benimsemesi durumudur. Çalışanlarda psikolojik sahiplenme aidiyet duygusu oluşturacağı için işe adanmışlık konusunda pozitif bir etkisinin bulunduğu söylenebilir (Pierce vd., 2001).

Yönetici desteği ve psikolojik sahiplenmenin işe adanmışlık üzerindeki olumlu etkisi ve yönetici desteğinin işe adanmışlık üzerindeki etkisinin arttırlmasında ise psikolojik sahiplenme arttırıcı bir etkisinin olup olmadı̆̆1 bu çalışmanın çıkış noktasını oluşturmaktadır. Yazın literatürde örgütsel destek bağlamında birçok çalışma bulunurken, yönetici desteği ve işe adanmışlık konusunda psikolojik sahiplenmenin rolü konusunda oldukça sınırlı sayıda çalısma bulunmaktadır. Bu nedenle yönetici desteği ve işe adanmışlık ilişkisinde psikolojik sahiplenmenin bu etkideki rolünün araştrrlması ise bu çalışmanın önemini ortaya koymaktadır.

Çalışma kapsamında oluşturulan araştırma soruları ise şu şekildedir:

- Yönetici desteği psikolojik sahiplenmeyi etkilemekte midir?

- Yönetici desteğinin işe adanmışlık üzerindeki etkisinde psikolojik sahiplenmenin aracıllk rolü bulunmakta midir?

Yukarda yer alan araştırma soruları çerçevesinde araştırmanın bundan sonraki kısmında kavramlar arası ilişkiler açıklanarak yapılan alan araştırması ile çalışma hipotezleri test edilmiş olup, ayrıca sonuç ve çıkarımlar kısmında ise elde edilen bulgular, uygulayıcılar ve bundan sonra yapılacak olan çalışmalara da 1şık tutacak şekilde ele alınmıştır. Bu duruma ek olarak, çalşsma sonucunda genel bir değerlendirme yapılmıştır. Bu durumda çalışmanın literatüre olumlu katkı yapacağı düşünülmektedir.

\section{Literatür Taraması ve Hipotezlerin Oluşturulması}

Yönetici desteği konusunda yapılan çalışmalarda, desteğin yüksek boyutlarda olduğu örgütlerde çalışanlarda yüksek memnuniyet oluştuğu, çalışanların iyi ilişkiler içerisinde oldukları ve psikolojik olarak rahatlamadan dolayı örgütsel sahiplenmenin daha fazla olduğu gözlemlenmiş̦tir (Anand vd., 2010). Bu konuda yapılan farklı bir çalışmada orta düzey yöneticilerin destekleri konusunda çalışanların algılamalarının bağlılık konusunda olumlu etkilerinin bulunduğunu ortaya koymuştur (Thomas, Bliese ve Jex, 2005). Buchanan (1974), yönetici desteği konusunda yapmış olduğu özellikle üst yönetim tarafindan desteklenen çalışanların duygusal bağlılıkları açısından anlamlı pozitif bir ilişkinin varlığından bahsetmiştir.

Literatüre bakıldığında yönetici desteği (YD) üzerine farklı tanımlamalar yapıldığını söyleyebilmek pek mümkündür. Yönetici desteği, iş görenlerin üyesi olduğu örgütün birinci sıradaki amirlerinden gördükleri destek olarak tanımlanabilir (Yoon ve Lim, 1999). Yönetici desteği, Burke ve diğerlerine (1992) göre, amir ve yöneticilerin örgüt ya da kurumda çalışan bireyler üzerinde oluşturduğu cesaret, destek ya da önemsenme algıları ile ilgili tutumlardır. Başka bir ifadeye göre, çalışanların üyesi oldukları örgütte görev yapan yöneticileri tarafından örgütsel anlamda destek görmeleri ve yönetici-çalışan arasında pozitif yönde 
bağ oluşturulması olarak ifade edilmektedir (Bhanthumnavin, 2003). Powell’a (2011) göre yönetici desteği, işyerlerindeki amirlerin uhdesinde çalısan bireylerin çalışmalarını takip etmesi ve çalışanların iyiliğini düşünüyor olmasıdır. Bir başka tanıma göre ise kurum ya da örgütte çalışan bireylerin motive edilmesi, teşvik edilmesi ve karşılaşılan problemlerin çözümünde onlara destek olunmasıdır (Babin ve Boles, 1996).

Organizasyonların sağlıklı yürütülmesi açısından yönetici desteğinin önemi bir hayli fazladır. Özellikle yürütülen iş ve işlemlerde çalışlan ortamın iyi olması, dostane bir iklim oluşturulması durumunda yönetici desteği daha etkin olur. Çünkü böyle bir ortamda amirler sahip oldukları yetkilerini daha rahat olarak kullanırlar (Yaşar vd., 2014). Demirhan ve diğerleri (2014) tarafindan Diyarbakır Emniyet Müdürlüğünde görevli Özel Harekat polisleri üzerinde yaptıkları yönetici desteğinin performansa etkisi konulu çalışmada, yönetici desteğinin çalıssanlarda örgütsel sahiplenme konusunda pozitif bir etkisi bulunduğunu söylemişlerdir. Gagnon ve Michael (2004) çalışmalarında yönetici desteğinin çalışan performansı ve örgütsel bağllık konusunda pozitif etkilerinin bulunduğunu ve De Coninck ve Johnson (2009) örgütlerde yönetici desteğinin çalışanların işe ve örgüte yönelik davranışlarını olumlu yönde etkilediğini ifade etmişlerdir.

Psikolojik sahiplenmeyi (PS) ilk olarak araştıran ve açılayan Pierce ve arkadaşlarıdır (2001). Yaptıkları çalışmada psikolojik sahiplenme duygusunun meydana geliş nedeni ve bu durumun çalışan motivasyonu üzerinde yaptığı değişikliklerden bahsetmişlerdir. Psikolojik sahiplenme (PS), örgüt ya da kurum ortamında çalışan bireylerin herhangi bir eşya ya da nesneyi kendilerine aitmiş gibi bir hissiyat içerisinde davranış göstermeleri durumudur (Ötken, 2015). Literatür yazın incelediğinde psikolojik sahiplenme ile ilgili tanımlar ve çalısmaların sınırlı olduğu görülmektedir. Yazında yapılan bazı tanımlamalara bakıldığında Pierce vd. tarafindan (1991) psikolojik sahiplenme iş görenlerin üyesi olduğu örgütle ilgili mülkiyet sahipliği kavramına yönelik olarak geliştirdikleri bir sahiplenme tarzı, Mayhew vd. (2007, s. 477) psikolojik sahiplenmeyi, mülkiyet hakkının resmi şartlar olmadan bile çalışanlar tarafindan benimsenmesi, Vandewalle vd. (1995, s. 211) göre ise çalışanların işyerinde herhangi bir hisseleri olmamasına rağmen yapılan iş ve işlemlere sahiplenme duygularının oluşması şeklinde ifade etmektedir. Bir başka tanıma göre psikolojik sahiplenme, hukuki düzlemde herhangi bir yetkisi ya da sahiplikleri olmamasına karşın çalışanların iş ve örgütünü sahiplenme duygusu olarak belirtilmektedir (Uçar, 2018).

Yönetici desteği ve psikolojik sahiplenme üzerine yapılan çalışmalarda bu çalışmanın amacını destekleyen bulgulara ulaşılmışır. Örneğin, Çıkmaz ve Yeşil (2020), Gaziantep ilindeki KOBİ niteliğinde çalışan işletmelerde görev yapan 326 çalşsan üzerinde örgütsel desteğin psikolojik sahiplenme üzerindeki etkisini ölçmeye yönelik bir araştırma yapmışlardır. Yapılan araştırma sonucunda ortaya çıkan olumsuz algıların psikolojik sahiplenmeyi de olumsuz olarak etkilediği sunucuna ulaşmışlardır. Ötken (2015), İstanbul ilinde birçok farklı sektörde faaliyet gösteren örgütlerdeki 250 çalşan üzerinde; Akçin (2018) devlet üniversitelerinde görev yapan 502 akademik personel üzerinde; Derin (2018) İnönü üniversitesinde görev yapan 355 kişi üzerinde yönetici desteğinin psikolojik sahiplenmeyi pozitif yönde olumlu olarak etkilediği belirlenmiştir. Bu doğrultuda yukarda belirtilen literatür ve çalışma bulgularından hareket edilerek yönetici desteği ve psikolojik sahiplenme arasındaki ilişkiyi belirlemeye yönelik olarak aşağıdaki hipotez oluşturulmuştur.

\section{H1. Yönetici desteği psikolojik sahiplenmeyi pozitif yönde etkilemektedir.}

İşe adanmışlık (İA), çalışanların görev yaptığı kurum ya da örgüt içerisinde kendilerine tevdi edilen işlerine odaklanarak işlerini en iyi şekilde severek yapmalarını ifade etmektedir (Turhan vd., 2012, s. 180). Başka bir tanıma göre işe adanmışlık, iş görenin yapmış olduğu işle kendisini bütünleştirmesidir (Chusmir, 1982, s. 596). Çalışanların örgüt çatısı altında yaptıkları iş ve görevlerine karşı beslediği tutku ve bağlılıktır (Bakker ve Demerouti, 2008, s. 209). Bir başka açıdan işe adanmışlık, çalışanların yapmış oldukları işe duygusal enerjilerini de katarak yapmaları ve içerisinde bulunduğu iş ortamına adapte olarak işini büyük bir aşkla yapmalandır (Kahn, 1990, s. 694). Bu bağlamda, bir çalışanın işe adanmışlığı örgüt çatısı altında birlikte çalıştı̆̆ arkadaşları arasındaki ilişkilere, hizmet verdiği kişilerle olan iletişimine, işte gösterdiği performansına, iş arkadaşlarının iş ortamında ortaya koyduğu tutum ve davranışlara göre değişmektedir (Sağsan ve Fırtına, 2015, s. 7). İşe adanmışlık kavramı genel olarak literatürdeki bazı kavramlarla karşılaştırıldığında örneğin örgütsel adanma kavramı ile benzerlikler gösterse bile kendi içerisinde farklı bir kavramdır. Örgüt sadakatinde çalışan örgüte yönelik bir sadakat ortaya koyarken, işe adanmışlığın hedef noktası ise tamamen işin kendisidir (Ardıç ve Polatc1, 2009, s. 37).

İşe adanmışlık konusundaki çeşitli çalışmalarda, bu tür çalışanların; diğer çalışanlara göre daha yüksek motivasyona sahip olduklan, örgütü sahiplenme konusunda daha istekli gözüktükleri, iş yapma 
becerilerinin üst seviyede olduğu, olaylara karşı daha fazla inisiyatif kullandıkları, gelişime açık oldukları ve işte ayrılma niyetlerinin ise düşük seviyede bulunduğu saptanmıştır (Bakker vd., 2008). Karagöz (2008) yönetici desteği üzerine yapmış olduğu çalışmada, yönetimin desteğinin çalışanların işe adanmışlıklarını pozitif yönde etkilediğini bulmuştur. Powell’a (2011) göre çalışanların motivasyonu konusunda ve işe adanmışl1k teşvik edilmesi için yönetici desteği oldukça önemlidir Goh vd. (2015) sağllk sektörü üzerine yürüttükleri çalışmalarında yönetici desteğinin ile iş doyumu arasında pozitif bir ilişki saptamışlardır ve örgütsel başarı için yönetici desteğinin önemli olduğunu vurgulamışlardır. Demir (2012) havalimanı yer hizmetleri çalışanları üzerinde yaptığı çalışmada örgütsel destek ile örgütsel bağll1ık ve adanmışlık arasında pozitif ilişkiler bulmuştur. Yine bir başka benzer çalışmada ise İnce (2016) bir konfeksiyon firmasında çalışan 307 katılımcı üzerinde algılanan örgütsel desteğin işe adanmışlık üzerindeki etkisinde yönetici desteğinin bir aracilık rolü olup olmadığını araştırmıştır. Yapılan bu araştırma sonucunda yönetici desteğinin tam aracıllk rolü olduğu sonucunu tespit emiştir. Işı1k ve Kama (2018) tarafindan Bitlis ili Tatvan ilçesinde görev yapan 378 öğretmen üzerinde algılanan örgütsel desteğin iş gören performansına etkisinde işe adanmışlı̆̆n aracı etkisi olup olmadığını araştırılmıstır. Araştırma sonucunda fiziksel adanmışlğın kısmi aracı etkiye sahip olduğu sonucuna ulaşmışladır.

Yapılan araştırma sonucunda, yönetici desteğinin işe adanmışlık üzerindeki etkisinde psikolojik sahiplenmenin aracı rolüne ilişkin literatürde herhangi bir çalışmaya rastlanılmamıştır. $\mathrm{Bu}$ nedenle psikolojik sahiplenmenin varsa aracı rolünün örgütler, yöneticiler ile çalışanlar açısından ortaya konulması ve ayrıca literatüre katkı yapacak olması bakımından çalışma önemli görülmüş ve araştırmanın ana hipotezi aşağıdaki gibi belirlenmiştir. Yukarıda yer alan teori ve çalışma bulguları ışığında yönetici desteğinin işe adanmışlı üzerindeki etkisinde psikolojik sahiplenmenin artırıcı etkisinin olduğu düşünülmektedir. $\mathrm{Bu}$ doğrultuda aşağıldaki hipotez oluşturulmuştur;

H2. Yönetici desteğinin işe adanmışlık üzerindeki etkisinde psikolojik sahiplenmenin aracı rolü vardır.

\section{Yöntem}

Yönetici desteğinin işe adanmışlık üzerindeki etkisinde psikolojik sahiplenmenin aracı rolünü belirlemeye yönelik olan bu çalışmada, öncelikle araştırmanın evren ve örneklemi ile araştırmada kullanılan ölçeklere dair bilgiler verilmiştir. Sonra araştırma örnekleminden elde edilen veriler 1şığında oluşturulmuş olan araștırma modeline yönelik analizler yapılmıştır. Bu doğrultuda çalışmanın ölçeklerine ilişskin doğrulayıcı faktör analizleri (DFA) yapılmış ve araştırma değişkenleri arasındaki korelasyonlar tespit edilmiştir. Daha sonrasında ise araştırma modeli çerçevesinde kurulan yapısal eşitlik modeli ile araştırma modelinin uyum iyiliği testleri yapılmış ve değişkenler arası regresyon analizi ve aracıllk testi sonuçları sunulmuştur.

\section{Araştırmanın Modeli}

Literatür ve hipotezler doğrultusunda değişkenlerin birbirleriyle olan ilişkileri ortaya koymak amaciyla aşağıdaki araştırma modeli oluşturulmuştur. Yapılan bu araştırmada, Karasar'ın (1995) belirttiği gibi; iki ve daha fazla sayıda değişkenin ilişki içinde olma durumunu ve birlikte bir değişimin olup olmamasını tespit etmeye çalışan araştırma modeli olan ilişskisel tarama modeli tercih edilmiştir. Şekil 1'de üç farklı değişkeni konu alan araştırmanın kavramsal modeli gösterilmiştir.

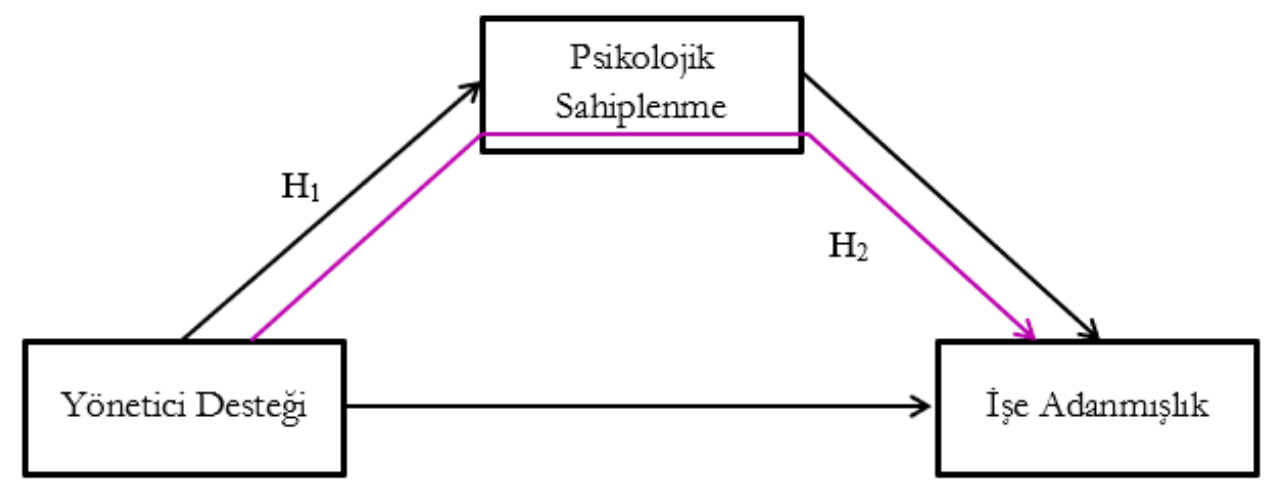

Şekil 1. Araştırma Modeli 


\section{Araştırmanın Evren ve Örneklemi}

Araştırmanın evrenini Çanakkale Bölgesel Yürütme Kurulu'na bağlı Balıkesir ve Çanakkale illerinde faaliyet gösteren seyahat acentesi işletmeleri oluşturmaktadır. Örneklemi ise kolayda örnekleme yöntemiyle seçilmiş Balıkesir ve Çanakkale illerinde faaliyet gösteren seyahat acentesi çalışanlarıdır. Zaman ve maliyet sınırlılığından dolayı rastgele seçilmiş olan 142 adet seyahat acentesinde çalışan 300 kişiye anket yapılması planlanmıştır. Dağıtılan anketlerin 36'sı cevaplandırılmamıss, 19'unda ise eksik cevaplandırma olduğu için araştırmanın örneklemi 245 kişiden oluşmaktadır. Çalışanların 101'si kadın 144'ü ise erkektir. Çalışanların 76's1 18-30 yaş, 130 'u 31-40 yaş, 28 'si ise $41-50$ ve 11 kişisi ise 51 ve üzeri yaş aralığında yer almaktadır. İş deneyimi açısından çalışanların 13 'ü 1 yıldan az, 52'si 1-3 yll, 70'i 4-6 yıl, 43’ü 7-9 yll, ve 67'si ise 10 yll ve üzeri iş tecrübesine sahiptir.

\section{Veri Toplama Araçları}

Anket formlanndaki tüm ölçeklerdeki ifadeler 5'li Likert tipi ölçekle ölçülmüştür. Ölçeklerin güvenilirliği için Cronbach Alpha değeri kullanılmış olup; ölçeklerdeki tüm ifadeler için de ortalama ve standart sapma değerleri hesaplanmıştır. Anket formundaki ifadelerin tümündeki faktörlerin güvenilirlik değerlerinin 0,70 ve üstünde olduğu bulgulanmıştır (Nunnally, 1978).

Yönetici Desteği Ölçeği: Göktepe'nin (2017, s. 31-48), Eisenberg vd.'nin (1986, s. 500-607) 1986 yllından kalan ölçeklerini günümüze göre uyarlaması sonucu geçerliliği ve güvenirliliği analizlerini yaparak tespit ettiği 7 soru alınmıştır. Sorular somut ve soyut destek olarak adlandırılan 2 boyuta ayrılmıştır. İlk 4 soru somut, sonraki 3 soru soyut destek boyutu olarak tanımlanmıştır. Sözkonusu ölçeğin güvenilirlik katsayısı 0,91 olarak tespit edilmiştir.

İse Adanmışlık Ölçĕğ: Schaufeli ve Bakker (2003) tarafından geliştirilen ve Türkçe geçerlemesi Özkalp ve Meydan (2015) tarafindan yapılan üç boyut ve dokuz önermeden oluşan ölçek kullanılmıştır. Sözkonusu ölçeğin güvenilirlik katsayısı 0,94 olarak tespit edilmiştir.

Psikolojik Sabiplenme Ölçeğg: Van Dyne ve Pierce (2004) tarafindan geliştirilen ve Türkçe geçerlemesi Ötken (2015) tarafindan yapılan tek boyut ve 7 ifadeden oluşan ölçek kullanılmıştır. Doğrulayıcı faktör analizi neticesinde ölçeğin faktör yüklerinin .87 ile .91 arasında olduğu tespit edilmiştir. Sözkonusu ölçeğin güvenilirlik katsayısı 0,95 olarak tespit edilmiştir.

\section{Bulgular}

Araştırma kapsamında toplanan verilerin analizlerinin gerçekleştirilmesinde SPSS ve AMOS istatistik paket programlar kullanılmıştır. Çalışmada kullanılan ölçeklerin güvenilirlik düzeylerini ortaya koymak amacıyla Cronbach Alfa katsayısı dikkate alınmış ve değişkenlere ait betimleyici istatistikler tespit edilmiştir. Araştırmada ortaya konulan ölçüm modelinin yapısal geçerliğini belirlemek için doğrulayıcı faktör analizi (DFA) yapılmış ve ayış̧ma ile birleşme geçerlikleri ortaya konulmuştur. Bunlara ek olarak, araştırmada ele alınan değişkenler arasındaki ilişkiler Pearson korelasyon analizi yapılarak tespit edilmiştir. Çalışmada öne sürülen hipotezlerin test edilmesinde yapısal eşitlik modeli (YEM) analizi ele alınmış ve böylece değişkenler arasında ortaya konulması amaçlanılan doğrudan, dolaylı ve toplam etkiler tespit edilmiştir.

Değişkenler arasındaki korelasyon değerleri ve değişkenlere ait güvenirlilik ve betimleyici istatistikler Tablo 1'de yer almaktadır. Değişkenlerin ortalamalarına ait çarpıklık ve basıklık değerlerinin +2 ve -2 arasında yer alması verilerin iyi bir şekilde dağıldığını ifade edilmektedir. Aşağıda yer alan Tablo 1 incelendiğinde yönetici desteği, işe adanmışlık ve psikolojik sahiplenme değişkenleri arasında pozitif ve anlamlı ilişkiler olduğu bulgulanmıştır.

Tablo 1. Betimleyici İstatistikler ve Korelâsyon Katsaynlan

\begin{tabular}{lccccccc}
\hline & Ort. & Ss. & Çarp1kl1k & Basılklk & $\mathbf{1}$ & $\mathbf{2}$ & \\
\hline 1.Yönetici Desteği & 3.20 & .72 & .15 & .31 & $(.91)$ & \\
\hline 2.İşe Adanmışlık & 3.21 & .95 & -.24 & -.23 & $.648^{* *}$ & $(.94)$ \\
\hline 3. Psikolojik Sahiplenme & 3.37 & .91 & -.28 & .18 & $.536^{* *}$ & $.759^{* *}$ & $(.95)$ \\
\hline
\end{tabular}

${ }^{* *} \mathrm{p}<.001, \mathrm{n}=245$, parantez içerisinde verilen değerler Cronbach Alfa değerleridir.

Çalışmada öncelikle ölçeklerin geçerliklerini tespit etmek amacıyla birinci düzey çok faktörlü yapısı, AMOS programı tercih edilerek doğrulayıcı faktör analizi (DFA) ile test edilmiştir. Verilerin normal dağılım göstermesi nedeniyle bunun için en yüksek olabilirlik kestirim yöntemi (maximum likelihood) 
hesaplama yöntemi kullanılmıştır (Gürbüz ve Şahin, 2016). Ölçeğin birinci düzey doğrulayıcı faktör analizi (DFA) sonucunda işe adanmışlık faktörünün 'dinçlik' boyutuna ait bir madde düşük faktör yükü nedeniyle model dışı bırakılmış ve analiz tekrarlanmıştır. Tekrar yapılan birinci düzey doğrulayıcı faktör analizi (DFA) sonucunda uyum indeksleri değerlerinde kabul edilebilir iyi uyum değerlerine ulaşılmıştır. Söz konusu bulgulara göre faktör yükleri 0,712 ile 0,981 arasında değişen yüksek değerler almış olup, bu faktör yüklerinin tamamı istatistiksel olarak anlamlı bulunmuştur. Yapılan doğrulayıcı faktör analizi (DFA) sonuçları aşağıda tablo 2'de sunulmuştur. DFA neticesinde ulaşılan uyum iyiliği değerleri $(\chi 2 / \mathrm{df}=2.52$; SRMR $=0.72$; IFI $=0.94$; TLI $=0.93$; CFI $=0.94$; RMSEA $=0.79)$ olarak tespit edilmiş ve bu değerler modelin iyi uyum içerisinde olduğunu göstermektedir. Ayrıca bu sonuçlar, üç faktörün öngörülen kuramsal yapısının doğrulandığını ifade etmektedir.

Tablo 2. Ölçeklerin ve Araștrma Modelinin Uyum İiliü̆ Istatistikleri

\begin{tabular}{lllllllll}
\hline Uyum İyiliği Değerleri & $\chi^{2}$ & df & CMIN/DF & SRMR & IFI & CFI & TLI & RMSEA \\
\hline Yönetici Desteği & 21.694 & 12 & 1.808 & .021 & .991 & .991 & .998 & .058 \\
\hline İşe Adanmışlik & 31.720 & 14 & 2.266 & .018 & .991 & .991 & .983 & .072 \\
\hline Psikolojik Sahiplenme & 24.051 & 11 & 2.186 & .019 & .994 & .994 & .988 & .070 \\
\hline Ölçüm Modeli & 495.476 & 196 & 2.528 & .072 & .948 & .948 & .939 & .079 \\
\hline
\end{tabular}

Araştırmanın bundan sonraki kısmında ise araştırma hipotezlerinin ve aracilık etkisinin test edilebilmesi için yönetici desteğinin ișe adanmışlık üzerindeki etkisinde psikolojik sahiplenmenin arac1 rolüne ait bir yol analizi modeli kurulmuştur. Kurulan yapısal modele ilişkin sonuç Şekil 2'de gösterilmiştir.

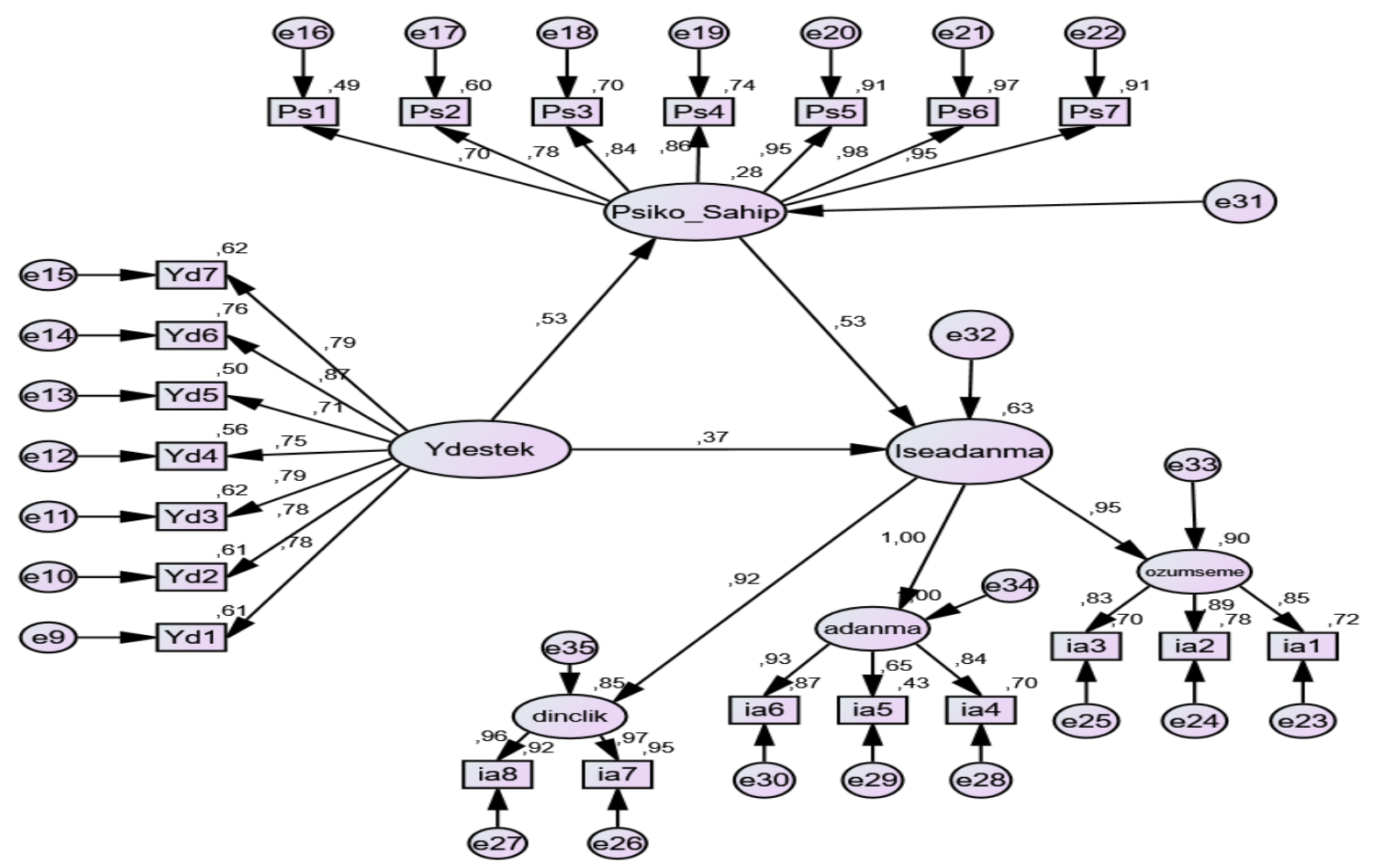

Şekil 1. Yapısal Eşitlik Modeli (YEM) ve Standartlaștırlmış Yol Katsaylar

Şekil 2'de verilen modele ilişkin H1 "Yönetici desteği psikolojik sahiplenmeyi pozitif yönde etkilemektedir." ve $\mathbf{H 2}$ "Yönetici desteğinin işe adanmışlık üzerindeki etkisinde psikolojik sahiplenmenin aracı rolü vardır." hipotezleri aracı modelin etkisini değerlendirmek üzere yapısal model üzerinden araştırma hipotezleri test edilmiş ve sonuçları Tablo 3'te gösterilmiştir. Aracilık rolünün testi için dolaylı etkilerin anlamlılı̆ına bakabilmek için monte carlo parametrik boostrap seçeneği ile 5000 örneklemden oluşan \%95 güven aralığında en yüksek olabilirlik yöntemi kullanılmıştır (Kara ve Kaya, 2020, s.1208). Güven aralıklarına ilişkin alt ve üst değerler Tablo 3 'te sunulmuştur. 
Tablo 3. Araculle Analizi

\begin{tabular}{|c|c|c|c|c|c|c|}
\hline \multirow{2}{*}{\multicolumn{3}{|c|}{ Test Edilen Yol }} & \multirow{3}{*}{$\beta$} & \multirow{3}{*}{ SE } & \multicolumn{2}{|c|}{ BC $\% 95$ CI } \\
\hline & & & & & & \\
\hline & & & & & & D \\
\hline Yönetici Desteği & $--->$ & Psikolojik Sahiplenme & $0,532^{* * *}$ & 0,49 & .43 & .62 \\
\hline Psikolojik Sahiplenme & $--->$ & İşe Adanmışlık & $0,534^{* * *}$ & 0,50 & .43 & .62 \\
\hline Yönetici Desteği & $--->$ & İşe Adanmışlık & & & & \\
\hline Toplam Etki (c) & & & 0,652 & 0,54 & .56 & .73 \\
\hline Doğrudan Etki (c') & & & $0,368^{* * *}$ & - & .26 & .47 \\
\hline Dolaylı Etki (axb) & & & $0,284^{* * *}$ & - & .22 & .36 \\
\hline
\end{tabular}

Analiz neticesinde yönetici desteğinin psikolojik sahiplenme üzerinde $(\beta=.532, \mathrm{p}<.001, \% 95$ CI [.43, .62]) pozitif yönde anlamlı bir etkiye sahiptir. Bu durumda $\mathbf{H 1}$ hipotezi desteklenmiştir. Bu sonuç, yönetici desteğinin, çalışanların yapılan işten dolayı işi psikolojik olarak sahiplenmelerini artırıcı bir etkisinin olduğunu göstermektedir. Psikolojik sahiplenme ise işe adanmışl1k üzerinde $(\beta=.534, \mathrm{p}<.001, \% 95 \mathrm{CI}$ $[.43, .62])$ pozitif yönde anlamlı bir etkiye sahiptir. Yine yönetici desteğinin işe adanmışlı üzerinde toplam $(\beta=.652, \mathrm{p}<.001, \% 95 \mathrm{CI}[.56, .73])$ ve doğrudan $(\beta=.368, \mathrm{p}<.001, \% 95 \mathrm{CI}[.26, .47])$ pozitif yönde anlamlı bir etkiye sahiptir. Ayrıca yönetici desteğinin işe adanmışlık üzerinde dolaylı $(\beta=.284, \mathrm{p}<.001$, $\% 95$ CI $[.22, .36])$ anlamlı etkisinin olduğu bulunmuştur. Bu durumda $\mathbf{H 2}$ hipotezi desteklenmiştir. Bu sonuçlar ışığında araştırmanın her iki hipotezi de kabul edilmiştir. Zhao vd. (2010) ve Baron and Kenny (1986)'a göre bir aracıllk etkisinden söz edebilmek için VAF (variance accunted for) değerinin hesaplanması gerektiğini, $\mathrm{VAF}<0,20$ aracilı etkisi yok, $0,20 \leq \mathrm{VAF} \leq 0,80 \mathrm{k}$ ssmi aracllı etkisi, $\mathrm{VAF} \geq 0,80$ tam aracilık etkisinin olduğunu açıklamışlardır (Chang, vd., 2019; Yang, vd., 2019; Sarstedt, vd., 2014; Klarner, vd., 2013). $V A F=\frac{\text { Dolaylı etki }}{\text { Dolaylı etki+Direk etki }}=\frac{0,28}{0,28+0,36}=0,44<0,80$ olduğu için modelde psikolojik sahiplenmenin kısmi aracilık etkisine sahip olduğu söylenebilir. Bu bulgulara göre yönetici desteğinin işe adanmışlık üzerindeki etkisinde psikolojik sahiplenmenin "kısmi aracılık rolü" vardır. Zira yüzdelik yöntem ile elde edilmiş Boostrap alt ve üst güven aralı̆̆1 değerleri, 0 (sıfir) değerini kapsamamaktadır (Kara ve Kaya, 2020, s. 1209). Bu bulgu ise psikolojik sahiplenmenin, temel amac1 çalışanlarına ve onlara destek çıkarak gayretlerini arttırmak olan yönetici desteğinin işe adanmışlk üzerindeki etkisinde artırıcı bir etkisinin olduğunu göstermektedir.

\section{Tartışma, Sonuç ve Öneriler}

Günümüzde iş dünyasında yaşanan rekabet ortamındaki gelişmeler örgütlerde yetenekli ve işine bağlı çalışanların varlığını zorun hale getirmiştir. Bu bağlamda çalışanların üyesi olduğu örgüt ya da kuruma psikolojik olarak sahiplenme ve işe adanma duygularının ön plana çıkarılması ancak başarılı bir yönetici desteği ile mevcuttur. Yönetici desteğinin örgüt ortamında görev yapan çalışanlar açısından önemi fazladır. Kurum içerisinde çalısanların ortamlarının iyileştirilmesi, motive edilmesi ve yapılan işe psikolojik olarak sahiplenme hislerinin arttırılmasında önemli bir rol üstlenmektedir. Özellikle son ylllarda çalışanların işe adanma ve psikolojik sahipliklerinin artırılmasında işletmeler açısından da giderek önemi artan bir konu haline gelmiştir. Bu önemden hareketle yönetici desteğinin işe adanmışlık üzerindeki etkisinde psikolojik sahiplenmenin aracılık rolünü belirlemek amacıyla Balıkesir ve Çanakkale illerinde faaliyet gösteren seyahat acentelerindeki çalışan personel üzerinde yapılan bu araştırmada anket aracıllğıyla toplanan veriler analiz edilmiştir.

Analiz neticesinde yönetici desteğinin psikolojik sahiplenmeyi pozitif yönde anlamlı olarak etkilediği tespit edilmiştir. Tespit edilen bu bulgu yönetici desteğinin psikolojik sahiplenme üzerindeki etkisini tespit etmek amaciyla yapilan (Hutchison, 1997; McIntyre vd., 2009; Van Dyne ve Pierce, 2004; Wayne vd., 1997; McIntyre vd., 2009; Nowakowski ve Conlon, 2005) araştırma sonuçlarıyla benzerlik göstermektedir. $\mathrm{Bu}$ bulgu yönetici desteğinin olması durumunda çalışanların psikolojik sahiplenme hislerini arttırdığını göstermektedir. Pierce vd. (2003) de belirttiği gibi kurum ya da örgüt içerisinde amirlerin yönetici desteği ile ilgili tutum ve davranışlar sergilemeleri durumunda çalışanların psikolojik sahiplenme düzeylerinde olumlu bir artış olacağını ifade etmektedir. Bu bulgu (Ötken, 2015) "çalışanların üyesi olduğu örgüte karşı bir sahiplik hissetmekte ve örgüte bağlanmakta ve örgüt, çalısanın kimliği olarak görülmektedir" ifadesine katk1 sunmaktadır. Bu duruma paralel olarak, psikolojik sahiplenme sahip olunan iş, görev ya da kuruma 
karş1 bir sorumluluk ve merak duygusunu da beraberinde getirmektedir. Kurum ya da örgüte karş1 psikolojik sahiplenme hissi içerisinde olan çalışanlar, örgütün geleceği için gönüllü olarak sorumluluk almakta ve örgütün refahı için bir çaba göstermektedirler (Baer ve Brown, 2012). Ayrıca Alp’inde (2007) ifade ettiği gibi çalışan personelin sahiplik hissi, örgüt için ağır sayılabilecek paylaşım hislerinin ve sorumluluk bilincinin birbirlerine refakat etmesiyle artar. Nitekim bu farklı yaklaşımlar çalışanlar üzerinde de olumlu etkiler bırakmakta ve çalışanın işine sahiplenmesine imkân tanımaktadır. Saptanan bu bilgiye göre yönetici desteği ile çalışanların sosyo-psikolojik ihtiyaçlarının da karşılanabileceği değerlendirilmesi yapilabilmektedir.

Araştırmanın ana amacına yönelik yapılan yönetici desteğinin işe adanmışlık üzerindeki etkisinde psikolojik sahiplenmenin aracı rolünün tespit edilmesine yönelik yapılan analiz neticesinde ise yönetici desteğinin işe adanmışlı üzerindeki etkisinde psikolojik sahiplenmenin kısmi aracı rolü olduğu sonucu tespit edilmiştir. Tespit edilen bu sonuç, yönetici desteğinin işe adanmışlık üzerindeki etkisinde gerek doğrudan gerekse de psikolojik sahiplenme aracıllı̆̆yla dolaylı bir etkisinin olduğunu göstermektedir. $\mathrm{Bu}$ açıdan çalışanlarda işe adanmışlık duygularının arttırılması için yönetici desteği ile motive edici bir verimli ortamın sağlanması ve çalışanların örgüt ve işe yönelik olarak daha fazla psikolojik sahiplenebilmeleri için ekonomik açlardan tatmin düzeylerinin iyileştirilmesi gerektiği düşünülmektedir. Bu bulgular yönetici desteği ve işe adanmışlı arasındaki ilişkiyi inceleyen (Turhan vd., 2012; Schaufeli ve Bakker, 2004; Demerouti vd., 2001; Sonnentag, 2003) çalısma sonuçlarıyla uyumludur. Çekmecelioğlu'nun (2007) belirttiği gibi, çalışmasında yönetici desteği çalışanların moral ve konsantrasyonlarını arttırmaları halinde çalışanların mevcut işlerine olan adanmışlık duygularının derecelerinde bir yükselme olduğu sonucuna ulaşmıştır." bu bulgu yönetici desteğinin işe adanmışlık üzerinde bir etkisinin var olduğu gerçeğini kuvvetlendirmektedir. Yine tespit edilen bu bulguya göre yönetici desteği alan çalışanların sosyo-ekonomik ve duygusal ihtiyaçlarının karşılanması psikolojik sahiplenme güdüsünü arttırdığı değerlendirmesi ile ifade edilebilmektedir. Tüm bu bilgilerden hareketle seyahat acentelerinde görev yapan çalışanlann yönetici desteği görmeleri durumunda işe psikolojik sahiplenme ve işe adanmışlık duygularında bir artış olacağı bu durumunda doğal sonucu olarak acente satış ve gelirlerinde bir artış olacağına işaret olarak açılanabilir.

Araştırmada kullanılan ölçekler 5'li Likert skalasında olup, belirli ifadelere katılıp katılmamayı tespit etmek amacıyla oluşturulmuşlardır. Ancak değişkenler için aynı ölçek tipinin (Likert, semantik farklılıklar vb. ölçek türlerinin) kullanılması sonucu, ortak yöntem sapması oluşabilir. Bu durum, her üç değişkenin de Likert yöntem ile belirlenmiş olmasını ve anketi dolduranların düşünceleri üzerinde bir etki olabilme ihtimalini ifade eder (Güğerçin ve Ay, 2016). Dolayısıyla araştırmada kullanılan ölçeklerin 5'li Likert skalasında olması, araştırmanın sınırlılıklarından birisidir. Araştırmanın sadece bir bölgede, hizmet sektöründe faaliyet gösteren çalışanlar ile yapılması araştırmanın bir diğer sınırlılı̆̆ını oluşturmaktadır. Fakat bu çalışma neticesinde elde edilen tüm sonuçların üzerinde araştırma yapılan örneklem, belirlenen anket yöntemi ve araştırma sınırllıkları çerçevesinde değerlendirilmesi gerekir. Ayrıca, bu çalışmanın yapıldığı zaman dilimi içerisinde katılımcılar tarafından ortaya konan algı, tutum ve davranışların ilerleyen zaman içerisinde değişebilme ihtimali olmasından dolayı bu çalışma gerçekleştirildiği zaman ile kısıtlıdır. Bu nedenle, benzeri bir araştırmanın farklı sektör ve çalışanlar da uygulanması araştırmacılar için önerilebilir.

Bu çalışmanın literatüre en önemli katkısının yönetici desteğinin işe adanmışlı üzerindeki etkisinde psikolojik sahiplenmenin arttırıcı bir etkisi olduğunu kanıtlamış olmasıdır. Ayrıca literatürde bu üç değişkenin bir arada ele alınarak yapılan hiçbir bir çalışmanın olmayışı da bu araştırmanın önemini göstermektedir. Bu açıdan araştırmanın literatüre katkı sağlayacağı düşünülmektedir. Gelecekte yapılacak olan çalışmalar için ise algılanan örgütsel destek, örgütsel bağlllı, yetenek yönetimi gibi değişkenlerin çalş̧an performansı ve iş tatmini üzerindeki etkisinde personel güçlendirmenin aracı değişken olarak ele alan çalışmaların yapilması önerilmektedir. Uygulayıcılara yönelik ise kurum ya da işletmede ücret ve motivasyona yönelik olumlu yönetici desteği algisının örgüt-çalışan etkileşiminde önemli bir husus olduğu gerçeğinin göz ardı edilmemesi gerektiği önerisi yapılmaktadır. Buna ek olarak, çalışanların işe adanmışlık ve psikolojik sahiplenme duygularının arttrılması için ise amir ve yönetici durumunda olanların adaletli ve herkese eşit mesafede bir yönetim felsefesi ile yaklaşması ve çalışanların işe daha çabuk ve daha fazla adanmalarını sağlayacak ücretle ilgili tatmin düzeylerini yükseltecek çalısmaların yapılması tavsiye edilmektedir. 


\section{Etik Beyan}

"Yönetici Desteğinin İse Adanmışlı Üzrerindeki Etkisinde Psikolojik Sabiplenmenin Aracı Rolü” başlıklı çalışmanın yazım sürecinde bilimsel, etik ve alıntı kurallarına uyulmuş; toplanan veriler üzerinde herhangi bir tahrifat yapılmamış ve bu çalışma herhangi başka bir akademik yayın ortamına değerlendirme için gönderilmemiştir.

\section{Kaynakça}

Akçin. K. (2018). Calsşanlarn örgütsel destek algıst ve psikolojik sabiplenmelerinin sessiz̨lik davranışlarna ve görev performansina etkisi: Ë̆itim sektöründe bir arasttrma (Doktora Tezi). Uludağ Üniversitesi, Sosyal Bilimler Enstitüsü, Bursa.

Alp, M. (2007). Örgütlerde psikolojik sabiplenme ve örgütsel vatandaşllk (Yüksek Lisans Tezi). Kütahya Dumlupınar Üniversitesi Sosyal Bilimler Enstitüsü, Kütahya.

Anand, S., Vidyarthi P. R., Liden R. C. ve Rousseau, D. M. (2010). Good citizens in poorquality relationships: Idiosyncratic deals as a substitute for relationship quality. The Academy of Management Journal (AMJ), 53(5), 970988.

Ardıç, K. ve Polatcı, S. (2009). Tükenmişlik sendromu ve madalyonun öbür yüzü: İşle bütünleşme. Erciyes Üniversitesi İktisadi ve İdari Bilimler Fakïltesi Dergisi, 32, 2146.

Babin, B. J. ve Boles, J. S. (1996). The effects of perceived co-worker involvement and supervisor support on service provider role stress, performance and job satisfaction. Journal of Retailing, 72(1), 57-75.

Baer M. ve G. Brown (2012). Blind in one eye: How psychological ownership of ideas affects the types of suggestions people adopt. Organizational Behavior and Human Decision Processes, 118, 60-71.

Bakker, A. B., Schaufeli, W. B., Leiter, M. P. ve Taris, T. W. (2008). Work engagement: An emerging concept in occupational health psychology. Work \& S Stress, 22(3), 187-200.

Bakker, A. B. ve Demerouti, E. (2008). Towards a model of work engagement. Career Development International, 13(3), 209-223.

Baron, R. M. ve Kenny, D. A. (1986). The moderator-mediator variable distinction in social psychology research: conceptual, strategic and statistical considerations. Journal of Personality and Social Psychology, 51(6), 1173-1182.

Bhanthumnavin, D. (2000). Importance of supervisory social support and its implications for HRD in Thailand. Psychology and Developing Societies, 12(2), 155-166.

Buchanan, B. (1974). Building organizational commitment: The socialization of managers in work organizations. Administrative Science Quarterly, 19(1), 533-546.

Burke, M. J., Borucki, C. C. ve Hurley, A. E. (1992). Reconceptualizing psychological climate in a retail service environment: A multiple stakeholder perspective. Journal of Applied Psychology, 77(5), 717-729.

Chang, S. H., Shu, Y., Lin, Y. H. ve Wang, C. L. (2019). "I Believe", "I Think", Then "I Will"? Investigating the mediator role of ethical judgment between internet ethical self-efficacy and ethical behavioral intention. Computers in Human Behavior, 101, 387-393.

Chusmir, L. H. (1982). Job commitment and the organizational woman. Academy of Management Review, 7(4), 595-602.

Çekmecelioğlu, H. G. (2007). Yönetim desteği, örgütsel vatandaşlık davranışı ve performans arasındaki ilişkilerin değerlendirilmesi. 15. Ulusal Yönetim Organizasyon Kongresi Bildirileri, Sakarya Üniversitesi, s. 185-192.

Çıkmaz, G. ve Yeşil S. ( 2020). Çalışanların algıladıkları örgütsel desteğin psikolojik sahiplenme üzerine etkisi. Uluslararası Toplum Arastrmalar Dergisi, 10(22), 12-34.

DeConinck, B. J. ve J. T. Johnson. (2009). The effects of perceived supervisor support, perceived organizational support, and organizational justice on turnover among salespeople. Journal of Personal Selling \& Sales Management. 29(4), 333-350.

Demerouti, E., Bakker, A. B., De Jonge, J., Janssen, P. P. ve Schaufeli, W. B. (2001). Burnout and engagement at work as function of demands and control. Scandinavian Journal of Work Environment and Health, 27(4), 279-286.

Demir, M. (2012). Örgütsel destek, örgütsel bağlllık ve işten ayrılma eğilimi ilişkisi: havalimanı yer hizmetleri işletmelerine yönelik bir araştırma. "Iș, Gǚs" Endïstri İlişkileri ve Insan Kaynaklar Dergisi, 14, 47-64.

Demirhan, Y., Kula, S. ve Karagöz, G. (2014). İş memnuniyeti ve yönetici desteğinin memurların performanslarına etkisi: Diyarbakır özel harekat polis birimi örneği. Süleyman Demirel Üniversitesi İktisadi ve İdari Bilimler Fakiultesi Dergisi, 19(1), 285-297.

Derin, N. (2018). Kuruma duyulan psikolojik sahiplenme ile yenilikçi iş davranışı arasındaki ilişkide sanal kaytarmanın düzenleyici rolü. Hacettepe Üniversitesi İktisadi ve İdari Bilimler Fakültesi Dergisi, 36(1), 63-81.

Eisenberg, R., Huntingto, R., Hutchison, S. ve Sowa, D. (1986). Perceived organizational support. Journal of Applied Psychology, 71(3), 500-607.

Gagnon, M. A. ve Michael, J. H. (2004). Outcomes of perceived supervisor support for wood production employees. Forest Products Journal, 54(12), 172-177.

Goh, Z., Ilies, R. ve Wilson, K. S. (2015). Supportive supervisors improve employees' daily lives: The role supervisors play in the impact of daily workload on life satisfaction via work-family conflict'. Journal of Vocational Behavior, 89, 65-73.

Göktepe, E. A. (2017. Algilanan yönetici desteği ölçeği geliştirilmesi, geçerliliği ve güvenirliliği. İstanbul University, Journal of the School of Business, 46, 31-48. 
Güğerçin, U. ve Ay, Ü. (2016). Etik konumun örgütsel vatandaşlık davranışı üzerindeki etkisi: Etik konum kuramı çerçevesinde bir analiz. KMÜ Sosyal ve Ekonomik. Araştırmalar Dergisi, 19(32), 34-46.

Gürbüz, S. ve Şahin, F. (2016). Sosyal bilimlerde araștırma yöntemleri felsefe, yöntem, analiz. (3. Bask1). Ankara: Seçkin Yayınc1lik.

İnce, R. A. (2016). Algılanan örgütsel desteğin işe adanmışlık üzerindeki etkisinde yönetici desteğinin aracıllk rolü. Elektronik Sosyal Bilimler Dergisi, 15(57), 649-660.

Kahn, W. A. (1990). Psychological conditions of personal engagement and disengagement at work. Academy of Management Journal, 33(4), 692-724.

Kara, E. ve Kaya, A. (2020). Dönüşümcü liderliğin çalışan performansı üzerindeki etkisinde iş tatminin arac1 rolü. Ücüncü Sektör Sosyal Ekonomi Dergisi, 55(2), 1202-1216.

Karagöz, A. (2008). İlk ve ortä̈ğretim okulu yöneticilerinin öğretmenler tarafindan algzlanan etik liderlik rolleri ile öğretmenlerin örgütsel adanmışlıklar arasindaki ilişki (Yüksek Lisans Tezi). Yeditepe Üniversitesi Sosyal Bilimler Enstitüsü, İstanbul.

Karasar, N. (1995). Bilimsel araștirma yöntemi: Kavramlar, ilkeler ve teknikler. Ankara: Sim Matbaas1.

Kırpık, G. (2020). Örgütsel davranış çalışmalarında yeni kavramlar: Google akademik (2019) ve SCI (2020) veri tabanlarına yönelik sistematik literatür taraması. İçinde M. Avcı ve E. Kara (Edt.), Örgütsel davranıs üzerine güncel çalsmalar. İstanbul: Hiper Yayın. ss. 13-51.

Kim, H. J., Hur, W. M., Moon, T. W. ve Jun, J. K. (2017). Is all support equal? The moderating effects of supervisor, coworker, and organizational support on the link between emotional labor and job performance. BRQ Business Research Quarterly, 20(2), 124-136.

Klarner, P., Sarstedt, M., Hoeck, M. ve Ringle, C. M. (2013). Disentangling the effects of team competences, team adaptability, and client communication on the performance of management consulting teams. Long Range Planning, 46(3), 258-286.

Mayhew, M. G., Ashkanasy, N. M., Bramble, T. ve Gardner, J. (2007). A study of the antecedents and consequences of psychological ownership in organizational settings. The Journal of Social Psychology, 147(5), 477-500.

Meydan, C. H. ve Şeşen, H. (2015). Yapısal eşitlik modellemesi: AMOS uygulamaları (2. Baskı). Ankara: Detay Yayıncıllk.

Nunnally, J. (1978). Psychometric methods (2nd Edition). New York. McGraw-Hill.

Ötken, A. B. (2015). Algılanan örgütsel destek ve psikolojik sahiplenme arasındaki ilişki ve bu ilişkide örgütsel adaletin rolü. Hacettepe Üniversitesi İktisadi ve İdari Bilimler Fakültesi Dergisi, 33(2), 113-140.

Özkalp, E. ve Meydan, B. (2015). Schaufeli ve Bakker tarafindan geliştirilmiş olan işe angaje olma ölçeğinin Türkçe'de güvenilirlik ve geçerliliğinin analizi. IS GUC The Journal of Industrial Relations and Human Resources, 17(3), 1-19.

Pierce, J. L., Tatiana, K. ve Kurt, T. D. (2001). Toward a theory of psychological ownership: In organization. Academy of Management Rewiev, 26(2), 298-310.

Pierce, J. L., Kostova, T. ve Dirks, K. (2003). The state of psychological ownership: integrating and extending a century of research. Review of General Psychology, 7, 84-107.

Powell, T. C. (2011). Behaviour strategy. Journal of Strategic Management, 32(13), 1369-1366.

Sağsan, M. ve Fırtına, B. (2015). Bilgi mesleğine bağlılık ve adanmışlık: platonik bir ilişkinin gelgitleri ve profesyonellikle imtihanı. Bilgi Dünyası Dergisi, 16(1), 1-22.

Sarstedt, M., Ringle, C. M., Smith, D., Reams, R. ve Hair Jr, J. F. (2014). Partial least squares structural equation modeling (PLS-SEM): A useful tool for family business researchers. Journal of Family Business Strategy, 5(1), 105115.

Schaufeli W. ve Arnold B. (2003). UWES Utrecht work engagement scale. http:// www.beanmanaged.com/doc/pdf/arnoldbak.ker/articles/articles_arnold_bak.ker_87.p df, Erişim Tarihi: 13. 02.2020

Schaufeli, W. B. ve Bakker A. B. (2004). Job demands, job resources and their relationship with burnout and engagement: A multi-sample study. Journal of Organizational Behavior, 25(3), 293-315.

Sonnentag, S. (2003). Recovery, work engagement and proactive behavior: A new look at the interface between nonwork and work. Journal of Applied Psychology, 88(3), 518-528.

Thomas, J. L., Bliese, P. D. ve Jex, S. M. 2005. Interpersonal conflict and organizational commitment: Examining two levels of supervisory support as multilevel moderators. Journal of Applied Social Psychology, 35, 2375-2398.

Turhan, M., Demirli, C. ve Nazik, G. (2012). Sınıf öğretmenlerinin mesleğe adanmışlık düzeyine etki eden faktörler: Elazığ örneği. İstanbul Ticaret Üniversitesi Sosyal Bilimler Dergisi, 11(21), 179-192.

Uçar, Z. (2018). Algılanan özerklik ve etki ile psikolojik sahiplenme arasındaki ilişkide kontrol algısının aracılık etkisi: Banka çalışanları üzerinde bir araştırma. Ege Akademik Bakış Dergisi, 18(1), 1-14.

Van Dyne, L. ve Pierce, J. L. (2004). Psychological ownership and feelings of possession: three field studies predicting employee attitudes and organizational citizenship behavior. Journal of Organizational Behavior, 25(4), 439-459.

Vandewalle, D., Van Dyne, L. ve Kostova, T. (1995). Psychological ownership: An empirical examination of its consequences. Group \& Organization Management, 20(2), 210-226.

Yang, Z., Tian, Y., Fan, Y., Liu, L., Luo, Y., Zhou, L. ve Yu, H. (2019). The mediating roles of caregiver social support and self-efficacy on caregiver burden in parkinson's disease. Journal of Affective Disorders, 256, 302-308. 
Yoon, J. ve Lim, J. C. (1999). Organizational support in the workplace: The case of Korean hospital employees. Human Relations, 52: 923-945.

Zhao, X, Lynch, J. G. ve Chen, Q. (2010). Reconsidering Baron and Kenny: Myths and truths about mediation analysis. Journal of Consumer Research, 37(2), 197-206.

\section{EXTENDED ABSTRACT}

Today, although the information and technology available to organizations are at a high level, the need for qualified personnel is increasing in the face of increasing and strengthened competitors. The definition of workforce in modern organizations is no longer defined as a force based on physical force. It is important to have employees who can see forward, come up with new ideas and produce value for their organizations. In this process, it can be said that the organizations that provide all kinds of support to their employees and who are closely interested in their development are more successful. The workforce policies that organizations have adopted in this success, as well as the attitudes and behaviors of the managers who put those policies into practice, can directly affect success or failure.

The starting point of this study is the positive effect of executive support and psychological ownership on devotion to work, and whether there is an effect of increasing executive support on devotion to work. While there are many studies in the literature in the context of organizational support in the literature, there are quite a limited number of studies on the role of psychological ownership in executive support and commitment to work. Therefore, investigating the role of psychological ownership in this effect in the relationship between executive support and work devotion reveals the importance of this study.

The research questions created within the scope of the study are as follows:

- Does executive support affect psychological ownership?

- Does psychological ownership have an intermediary role in the effect of executive support on work dedication?

Within the framework of the above research questions, the study hypotheses have been tested with the field research conducted by explaining the relations between the concepts in the next part of the research, and in the conclusion and conclusions, the findings have been handled in a way to shed light on the practitioners and the future studies.

In this study, which aims to determine the mediating role of psychological ownership in the effect of executive support on work devotion, firstly, information about the universe and sample of the research and the scales used in the research are given. Then, analyzes were made for the research model that was created in the light of the data obtained from the research sample. Accordingly, confirmatory factor analyzes (CFA) related to the scales of the study were made and correlations between the research variables were determined. Afterwards, the structural equality model established within the framework of the research model and the goodness of fit tests of the research model were conducted and the results of the regression analysis and mediation test between variables were presented.

In line with the literature and hypotheses, the following research model has been created in order to reveal the relationships between variables.

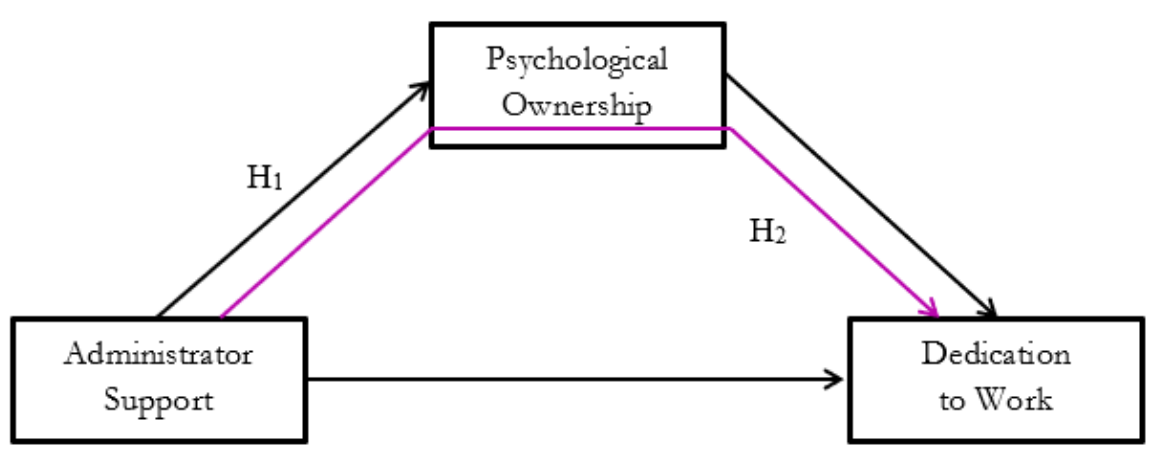

Figure 1. Research Model 
The universe of the research is Travel Agency companies operating in Balıkesir and Çanakkale provinces under the Çanakkale Regional Executive Board. The sample is the travel agency employees operating in Balıkesir and Çanakkale provinces selected by easy sampling method. It is planned to conduct a survey of 300 people working in randomly selected travel agencies due to time and cost limitations. The sample of the research consists of 245 people since 36 of the questionnaires distributed were not answered and 19 were incomplete answers. 101 of the employees are women and 144 are men. 76 of the employees are between the ages of 18-30, 130 are between the ages of 31-40, 28 are between the ages of 41-50 and 11 are between the ages of 51 and over. In terms of work experience, 13 of the employees have less than 1 year, 52 of them have 1-3 years, 70 of them have 4-6 years, 43 of them have 7-9 years, and 67 of them have 10 years of work experience.

Executive Support Scale: Göktepe’s (2017, pp. 31-48), Eisenberg et al. (1986, pp. 500-607) 7 questions that were determined by analyzing their validity and reliability by adapting their scales from 1986 according to today were taken. The reliability coefficient of this scale was determined to be 0.91. The Commitment to Work Scale: The scale, which was developed by Schaufeli and Bakker (2003) and whose Turkish validity was made by Özkalp and Meydan (2015), consists of nine propositions. The reliability coefficient of this scale was determined to be 0.94. Psychological Ownership Scale: The scale developed by Van Dyne and Pierce (2004) and whose validity in Turkish was made by Ötken (2015) and consists of 7 expressions.

As a result of the analysis conducted in order to determine the mediating role of psychological ownership in the effect of executive support on devotion to the main purpose of the research, it was determined that psychological ownership has a partial mediating role in the effect of executive support on job devotion. This result shows that the effect of executive support on devotion to work has a direct and indirect effect on psychological ownership. In this respect, it is thought that in order to increase the sense of commitment to employees, a motivating and productive environment with the support of managers and economic satisfaction levels should be improved in order for the employees to have more psychological ownership for the organization and work. These findings are consistent with the results of the study examining the relationship between executive support and devotion to work (Turhan et al., 2012; Schaufeli and Bakker, 2004; Demerouti et al., 2001; Sonnentag, 2003). As Çekmecelioğlu (2007) stated, in his study, executive support has reached the conclusion that if the employees increase their morale and concentration, there is an increase in the degree of commitment of employees to their current jobs. " this finding reinforces the fact that executive support has an impact on work devotion. 